\title{
INFILTRATION, EFFECTIVE POROSITY, TRANSMISSIBILITY AND CRITICAL YIELD OF WATER WELLS IN THE CARBONATE FISSURED AQUIFERS OF ATTICA - A CONTRIBUTION TO THE REGIONAL AND MANAGERIAL HYDROGEOLOGY
}

\author{
G. D. Kounis ${ }^{1}$ and K. G. Kounis ${ }^{2}$ \\ ${ }^{1}$ Hydrogeologist, Former Director of Hydrogeology,and Advisor at IGME, gdkounis@gmail.com \\ ${ }^{2}$ Consultant in Civil and Underground Works Engineering , kkouniscve@yahoo.com
}

\begin{abstract}
In the hydrogeological practice and the groundwater resources management the accurate knowledge on the infiltration, effective porosity, transmissibility, and on the sustainable yield of water wells is of fundamental value. It is so, because these parameters are the information primarily required in prediction and decisions relevant to the ground water abstractions and the hydrogeological evaluation of specific sites.
\end{abstract}

In this paper, we present these quantities from the carbonate fissured formations of Attica, non metamorphic (limestones, dolomitic limestones, dolomites) and metamorphic (marbles), which all are of great areal extent and thus of great interest for groundwater exploitation. In addition, they show good geomorphological, structural and lithologic resemblance with analogous formations elsewhere in this country, so that figures calculated can be reliably transferred for use.

In our work we used methods of increased reliability, and having known precipitation $(P)$ we estimated

- The Infiltration Index $\left(I_{c}\right)$ from the yield of springs of well defined hydrogeological catchments (natural lysimeters) and results found fall in the range of values

$$
0.38 P<I_{c}<0.42 P
$$

- The Effective Porosity $\left(p_{e}\right)$, obviously secondary because of the nature of the carbonate aquifers ( fissure flow aquifers ). We calculated it from groundwater level hydrograph and values found are in between

$$
1.31 \%<p_{e}<6.91 \%
$$

with the most common in between

$$
1.58 \%<p_{e}<4.8 \%
$$

- The Transmissibility $(T)$, we calculated from pumping tests, with Jacob method, using semilogarithmic plots of drawdowns ( $s$ ) versus time ( $t$ ) from start of pumping. Values found are mostly (70\%) in the range

$10 m^{3} / h . m<T<75 m^{3} / h . m$

- The Critical Yield $(Q c)$ of water wells we calculated from the "characteristic well curve" $Q$ $v s$. $s$ (with $Q$ and $s$ standing for yield and drawdown respectively). Values are mostly in between $15 \mathrm{~m}^{3} / \mathrm{h}<Q c<75 \mathrm{~m}^{3} / \mathrm{h}$.

Cretaceous limestones showed the best of the parameters, followed by the marbles free of schist in- 
tercalations and distant from schist boundary. Karstic processes on the fracture network, structures vulnerable to tectonic extension, like anticlines and tension faulting zones are the underlying reasons for better hydrogeologic performance and thus for higher values of the parameters studied. Dolomites outside the previous zones show very low values.

Key words : Attica, carbonate fissured, karstic aquifers, infiltration, natural lysimeters, effective porosity, critical yield, transmissibility.

\section{Introduction}

The experience, the senior of the authors has from the hydrogeology of the area of the wider Attica, after his work as a project manager and consultant (with IGME etc), raised the interest to go through the discussed hydrogeological issues and search them for more accurate approach, to the benefit of the hydrogeological practice. To this aim we examine basic quantities relative to the ground water study and exploitation and we introduce new and simple methods for the estimation of the critical yield of abstraction wells and of the specific yield ( effective porosity ) of aquifers .Further, we discuss the infiltration into the fissure flow carbonate aquifers and the transmissibility of same aquifers. We calculated infiltration index using natural lysimeters, it was found very representative and thus useful for further applications.

In addition, we present the generalized geological and hydrogeological structure and performance of the broader area to show the conditions under which the specified aquifers and sites of study perform.

\section{Hydrogeology}

\subsection{General}

The hydrogeological conditions of Attica almost fully conform to the geological and morphological structure. (Kounis et al., 2010).

Basic characteristics of almost all aquifers are their hydraulic continuity with sea, the low quality state at a distance of $4 \mathrm{~km}$ from the coastline, the low infiltration rate, and the limited purely confined conditions.

Though the two aquifer systems, of the intergranular flow and of the fissure flow, predominate in Attica, due to the complicated geologic structure and the geomorphology, different aquifers can be distinguished by their particular conditions and problems, the hydraulic continuity between units being absent or of minor hydrogeological importance.

In the fissure flow system (carbonate system), which is of primary importance in this presentation, two main factors govern the existing hydrogeological conditions, namely the fissure network which shows a varying degree of widening of its elements, subsequent to the karstification process, and the impermeable substratum. Although a diffused circulation of ground water through the carbonate masses can well be accepted as the rule in Attica, some localized, convergent flow along major faults and relevant fracture zones, especially in West Attica, is equally taking place. Internal solution of all kind of fracturing for karstification reasons is varying in space, more pronounced being in West Attica and in the cretaceous limestone. Schist layers and similar lithologic elements in the marbles of East Attica have resulted in a comparatively decreased karstification of the mass. Pure dolomites hardly transmit water, except along heavily fractured zones, while dolomitic limestones show very locally high transmissibility.

In West Attica the principal ground water divide coincides with the major anticlinical axis of Par- 


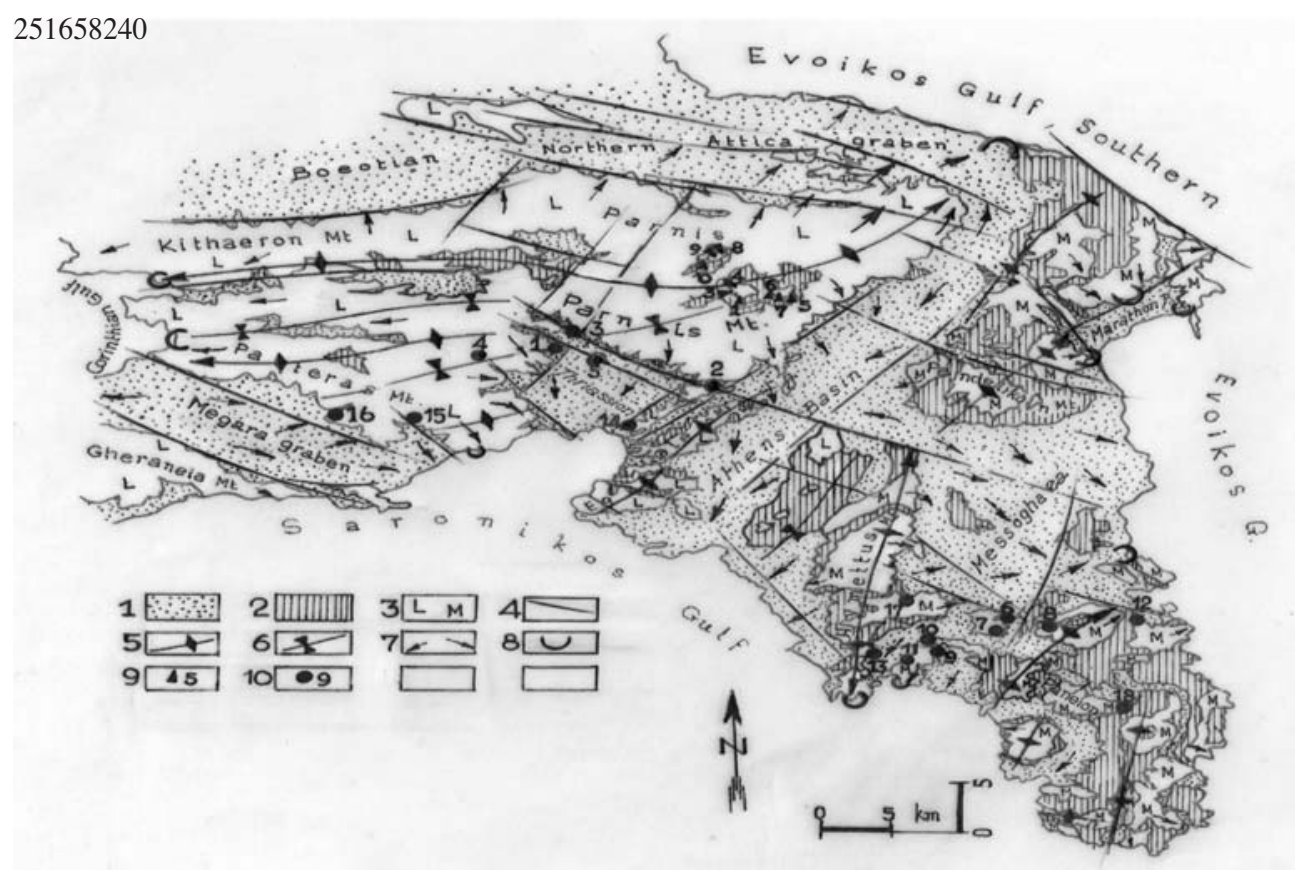

Fig. 1: Generalized hydrogeological map of Attica.

1.Dominantly clastics/low to moderately, very locally highly, yielding aquifers/aquitards and aquicludes ( quaternary and neogen). 2. Dominantly aquicludes and aquitards / flysch, shales, sandstones and schists/ metamorphic in east Attica /except of the flysch, underlain of carbonates in west Attica, overlain or interchanged with marbles in east Attica ( mesozoic, paleozoic). 3. Fissure, karstic flow aquifers, moderately to locally highly yielding / dominantly limestones, dolomites (L) and marbles (M) ( mesozoic). 4. Fault, chiefly in the preneogene structure . 5. Aticline .6. Synline. 7.Predominant GW flow. 8. GW discharge sites. 9. Springs with ref.no. 10. Borehole with ref. no.

nis-Kitheron Mt., along which the impermeable palaeozoic substratum crops out frequently. Approximately two thirds of the mass of the north limb of the anticline is drained to the Euboean Gulf, preferably by corverging flows to fractured zones and sites. Partial hydraulic interchange between the fissure and overlying porous system is evidenced. Ground water from the rest of the same anticlinal limb outflows to the Korinthian Gulf, again great faults being of prime importance in this drainage performance. The south anticlinal limb shows a rather diffused underground drainage pattern towards an extended front along Saronikos and Korinthian gulfs. A hydraulic relationship with the overlying porous system in low altitudes should he considered as a common situation. Due to a generally high slope gradient of the impermeable substratum in West Attica, circulation of water towards the saturation zone, formed approximately at sea level, is comparatively rapid and the mixing process with seawater therefore accentuated both in magnitude and areal extent.Water table in the saturation zone during dry season is formed at an average maximum of $10 \mathrm{~m}$ above sea level, and depths to it are commonly between $200 \mathrm{~m}$ and $300 \mathrm{~m}$, allowance being made for topography ,sea contamination and other technical and economic constraints.

In East Attica the main fissure aquifer is represented by the lower marble although other marble members in the lithological sequence are equally important, if not intruded by sea .Water table in lower marble is formed at an average maximum elevation of $5 \mathrm{~m}$ above sea level in dry season, 
higher elevations attained locally for tectonic mainly reasons. Common depths to the saturation zone are between $100 \mathrm{~m}$ and $230 \mathrm{~m}$, allowances made for the various constraints and the mean annual fluctuation is of $5 \mathrm{~m}$. The upper marble horizon of the lithologic sequence and other marble units show a saturation zone at higher elevations too, depended on the position of their impermeable schist substratum. In that case maximum depths are commonly under $150 \mathrm{~m}$. Final receptor of flows in marble aquifers is the sea, either directly or through some porous medium hydraulically placed in between. (Fig. 1, Kounis, 1998, 1986).

\subsection{Infiltration}

We studied two jurassic - triassic and one cretaceous fissured and moderately karstic, carbonate masses, with very well defined geologic boundaries on the Parnis Mt. All three have an aquiclude/aquitard substratum, the palaeozoic stratigraphically the first two, the flysch and tectonically the third. Also all are discharging their annual replenishment through contact springs (natural lysimeters) .These masses belong to the "Subpelagonic geotectonic zone" of Greece ( or "Eastern Greece geotectonic zone" and crop out at elevations in between $680 \mathrm{~m}$ and $1163 \mathrm{~m}$ above msl.

Data on springs discharge used are of six years (1976 - 1982) and are highly accurate .Of the same period are the data on precipitation taken from raingauge measurements, at the altitude of $1020 \mathrm{~m}$.asl. The raingauge site is in the near vicinity and on very close elevation to those of the masses studied, while it is also representative of the overall climatic conditions of the area of interest ( Mariolopoulos et al. 1955). The rest of the minor, influencing factors are the same (orientation, relief and inclination,vegetation etc), with the weathering mantle being moderate or thick and sporadic. Additionally, no other input and output except of that of precipitation and springs discharge respectively exists.

In table 1 the necessary data are given. From that, the very close results, as a calculated infiltration index (Ic), are revealed. A slight decrease of the index in the case of Platy Vouno and Borsi, in relation to that from Aghia Triada mass, is recognized, and as other geological factors are practically the same, we attribute the fact to the increased faulting that has brought about an increased fracturing, and preparation of surface karstification ( erosional depression and doline forms), to produce and sustain soil and vegetation cover.

The resulted average infiltration index is 0.397 , ie the infiltration of the water in the studied masses is the $39.7 \%$ of the precipitation on those masses. We calculate the infiltration index (Ic) as the ratio of the annual discharge (Qy) of the springs of a specified rock mass over the respective annual precipitation volume fallen on the area of the same mass.

The figure found we accept as a very accurate for further use in hydrogeological and natural water balance calculations. In addition, we suggest this as very representative for fissure flow carbonate aquifers, with moderately pronounced the surface karstic attack and forms, and more specifically for those of the "Eastern Greece geotectonic zone ".And this is mostly the case of the cretaceous and jurasic ,limestones, to a less extent of the triassic carbonates as well. Dolomitic component, especially if in abundance in the composition, as it is the case with the jurassic and particularly the triassic, reduces the infiltration index, sometimes considerably, in favour of the runoff for the decreased dissolubility and widening of the receiving the infiltration fissure network . Unless, and rarely, favourable but linear depleted depression forms have resulted from a strong faulting, without worthwhile soil and vegetation cover .

Finally, we think that values of the Ic appearing in various studies greater enough of those shown in the Table 1, either come out by the use of indirect methods of estimation, not fully applicable under 
Table 1.

\begin{tabular}{|c|c|c|c|c|c|c|c|c|c|}
\hline \multicolumn{3}{|c|}{ Feeding mass } & \multicolumn{4}{|c|}{ Springs } & \multicolumn{2}{|c|}{ Precipitation } & \multirow{3}{*}{$\begin{array}{c}\text { Qy/Vp } \\
\% \\
\text { Ic }\end{array}$} \\
\hline \multirow[t]{2}{*}{ Name } & \multirow{2}{*}{$\begin{array}{c}\text { Elevat.n } \\
\text { masl } \\
\text { max min }\end{array}$} & \multirow{2}{*}{$\begin{array}{c}\text { Area } \\
\mathbf{k m}^{2}\end{array}$} & \multirow{2}{*}{$\begin{array}{c}\text { Ref. } \\
\text { no }\end{array}$} & \multirow[t]{2}{*}{ Name } & \multicolumn{2}{|c|}{ Discharge } & \multirow{2}{*}{$\begin{array}{c}\text { Height } \\
\text { P,m }\end{array}$} & \multirow{2}{*}{$\begin{array}{l}\text { Volume } \\
\text { Vp, } \mathbf{m}^{3} \\
\text { /year }\end{array}$} & \\
\hline & & & & & $\begin{array}{c}\mathbf{Q} \\
\mathbf{m}^{3} / \mathbf{h}\end{array}$ & $\begin{array}{c}\mathbf{Q y} \\
\mathbf{m}^{3} / \mathbf{y}\end{array}$ & & & \\
\hline Platy & 1163 & & 1 & Roumani & 19.38 & & & & \\
\hline \multirow{3}{*}{ Vouno } & 820 & & 2 & Roumani & 4.68 & & & & \\
\hline & & & 3 & Kynigon & 4.01 & & & & \\
\hline & & & 4 & Goura & 53.53 & & & & \\
\hline $\begin{array}{l}\text { areal } \\
\text { figure }\end{array}$ & & 2.45 & & & 81.60 & 714816 & 0.7628 & 1868860 & 38.25 \\
\hline \multirow{3}{*}{$\begin{array}{l}\text { Aghia } \\
\text { Triada }\end{array}$} & & & 5 & Ag.Triada & 13.01 & & & & \\
\hline & 1150 & & 6 & Dhassikon & 5 & & & & \\
\hline & 990 & & 7 & Palaeochoriou & 26.75 & & & & \\
\hline \multirow{2}{*}{$\begin{array}{l}\text { areal } \\
\text { figure }\end{array}$} & & & & & & & & & \\
\hline & & 1.25 & & & 44.76 & 392098 & 0.7628 & 953500 & 41.12 \\
\hline \multirow[t]{4}{*}{ Borsi } & & & 8 & Ano Borsi & 13.40 & & & & \\
\hline & 902 & & 9 & Balkeva & 1.42 & & & & \\
\hline & 680 & & 10 & Mavromytou & 4.23 & & & & \\
\hline & & 0.55 & & & 19.05 & 166878 & 0.7628 & 419540 & 39.77 \\
\hline
\end{tabular}

the specified conditions of study or by an underestimated evapotranspiration in the natural water balance approach (Kounis et al., 2005).

\subsection{Effective porosity}

It is known as the ratio (pe) of the volume of the gravitational water contained, at saturation state, in a rock mass over the total volume of that mass (rock and water). It is the specific yield of the unconfined aquifers (Todd, 1959).

We made use of the groundwater hydrograph, from boreholes sunk in carbonate aquifer (limestones, dolomitic limestones and dolomites ) of the "Eastern Greece geotectonic zone ", in Attica .From such graphs we measured the annual ground water fluctuation $(\Delta \mathrm{H})$ and from the recession curve the annual recession $(\mathrm{Re})$, so that all height of infiltrating water in the aquifer is taken into account, as in the condition supposed that no groundwater outflow from the aquifer takes place. This total height, resulting from the annual difference between maximum and minimum $\mathrm{GW}$ level fluctuation plus the annual component of the height lost by the ground water flow, is the real quantity, the most reasonable and corresponding to the infiltration, and the method approaches very well the value for the effective porosity or the specific yield of the aquifer. 
Table 2.

\begin{tabular}{|c|c|c|c|c|c|c|c|c|c|}
\hline \multicolumn{2}{|r|}{ BH1 } & \multicolumn{2}{|r|}{ BH2 } & \multicolumn{2}{|c|}{ BH3 } & \multicolumn{2}{|r|}{ BH4 } & \multicolumn{2}{|c|}{ BH5 } \\
\hline $\begin{array}{c}\mathbf{H} \\
(\mathbf{m})\end{array}$ & $\begin{array}{c}\mathbf{R e} \\
\text { (m/day) }\end{array}$ & $\begin{array}{c}\mathbf{H} \\
(\mathbf{m})\end{array}$ & $\begin{array}{c}\operatorname{Re} \\
(\mathbf{m} / \mathbf{d a y})\end{array}$ & $\underset{(\mathbf{m})}{\mathbf{H}}$ & $\begin{array}{c}\mathbf{R e} \\
\text { (m/day) }\end{array}$ & $\begin{array}{c}\mathbf{H} \\
(\mathbf{m})\end{array}$ & $\begin{array}{c}\mathbf{R e} \\
(\mathrm{m} / \mathrm{day})\end{array}$ & $\begin{array}{c}\mathbf{H} \\
(\mathbf{m})\end{array}$ & $\begin{array}{c}\mathbf{R e} \\
(\mathbf{m} / \text { day })\end{array}$ \\
\hline 7.27 & $\begin{array}{c}(7.27- \\
6.99) / 49\end{array}$ & 8.31 & $(8.31-7.69) / 15$ & 9.46 & $\begin{array}{c}(9.46- \\
8.67) / 45\end{array}$ & 7.58 & $(7.58-7.23) / 48$ & 7.52 & $\begin{array}{l}(7.52- \\
6.86) / 9\end{array}$ \\
\hline & 0.00571 & & 0.0413 & & 0.0175 & & 0.00729 & & 0.0733 \\
\hline 6.99 & $\begin{array}{c}(6.99- \\
5.99) / 65\end{array}$ & 7.69 & $(7.69-7.06) / 53$ & 8.67 & $\begin{array}{c}(8.67- \\
8.53) / 19\end{array}$ & 7.23 & $(7.23-6.53) / 16$ & 6.86 & $\begin{array}{c}(6.86- \\
6.11) / 69\end{array}$ \\
\hline & 0.014 & & 0.0118 & & 0.00736 & & 0.04375 & & 0.0108 \\
\hline 6.24 & $\begin{array}{c}(6.24- \\
5.67) / 45\end{array}$ & 7.06 & $(7.06-6.9) / 54$ & 8.53 & $\begin{array}{c}(8.53- \\
7.51) / 49\end{array}$ & 6.53 & $(6.53-5.85) / 49$ & 6.11 & $\begin{array}{c}(6.11- \\
5.29) / 45\end{array}$ \\
\hline & 0.0126 & & 0.00296 & & 0.0208 & & 0.01382 & & 0.0182 \\
\hline & & & & 7.51 & $\begin{array}{r}(7.51- \\
7.2) / 54\end{array}$ & 5.85 & $\begin{array}{c}(5.85- \\
5.57) / 50\end{array}$ & & \\
\hline & & & & & 0.00574 & & 0.0056 & & \\
\hline & & & & & & 5.57 & $(5.57-5.41) / 48$ & & \\
\hline & & & & & & & 0.00333 & & \\
\hline $\mathbf{\Sigma R e}$ & 0.0333 & & 0.056 & & 0.05148 & & 0.0738 & & 0.102 \\
\hline & 0.0111 & & 0.0186 & & 0.01285 & & 0.01476 & & 0.034 \\
\hline $\begin{array}{l}\mathbf{R e}_{\mathbf{y}} \\
(\mathbf{m})\end{array}$ & 4.05 & & 6.789 & & 4.69 & & 5.387 & & 12.41 \\
\hline $\begin{array}{l}\Delta \mathbf{H} \\
(\mathbf{m})\end{array}$ & 1.6 & & 1.41 & & 2.26 & & 2.17 & & 2.00 \\
\hline $\begin{array}{r}\operatorname{Re}_{\mathrm{y}}+ \\
\Delta \mathbf{H}\end{array}$ & 5.65 & & 8.199 & & 6.95 & & 7.557 & & 14.41 \\
\hline I (m) & 0.2382 & & 0.2382 & & 0.2382 & & 0.2382 & & 0.2382 \\
\hline $\begin{array}{c}\mathbf{p}_{\mathrm{e}} \\
(\%)\end{array}$ & 4.21 & & 2.9 & & 3.42 & & 3.15 & & 1.65 \\
\hline
\end{tabular}

The calculation of the height (GW column) lost by recession was carried out in a few segments of the recession curve, as indicatively in the Table 2 is shown.

The recession curve, which is of the, widely used, general form of

$$
h t=h_{o} e^{-\lambda t},
$$

where $h_{t}, h_{0}, t, \lambda$,e stand for GW level at time $t$, at time 0 , recession coefficient and the neperian base of logarithms respectively of the GW hydrograph, is segmented, for linear/graphical solution, in few parts and is calculated at specified $h_{t}$ the slope $\Delta \mathrm{h} / \Delta \mathrm{t}$. Slopes found for the corresponding $\Delta \mathrm{ts}$ are summed up and mean value is taken. Time is given in days and recession loss of GW level is determined for the specified year. The found annual recession loss of GW level ( $R e$, in $\mathrm{m}$ ) is added to the respective fluctuation width. Finally, the effective porosity is estimated by the ratio 


$$
p e=I /(\Delta H+R e)
$$

where for the infiltration, in meters, we made use of the infiltration index we calculated for the same fissured carbonate aquifers of the area (2.2 above) and of the average precipitation, which is $600 \mathrm{~mm}$ at the average elevation of $500 \mathrm{~m}$.asl for the area studied. Data on the GW level are of 1982 which is a hydrological year of the time period considered in the calculation of infiltration of the paragraph 2.2.

In the Table 2 are $\mathrm{BH} 3$ the borehole, $\mathrm{H}$ the $\mathrm{GW}$ level elevation, from points on the recession curve of the GW hydrograph, $\mathrm{Re}=\Delta \mathrm{h} / \Delta \mathrm{t}$ the recession of GW level, $\Sigma \mathrm{Re}$ the sum of daily recession, the mean daily recession, $\mathrm{Re}_{\mathrm{y}}$ the annual recession, $\Delta \mathrm{H}$ the annual $\mathrm{GW}$ fluctuation ( $\mathrm{hmax}-\mathrm{hmin}$ ), I the annual infiltration, $\mathrm{p}_{\mathrm{e}}$ the effective porosity( specific yield).

\subsection{Transmisibility}

Transmissibility values (T) come out of the Jacob approach in unsteady state conditions of pumping tests and are by $93 \%$ less than $55 \mathrm{~m}^{3} / \mathrm{h} . \mathrm{m}$, while by $43 \%$ are less than $11 \mathrm{~m}^{3} / \mathrm{h} . \mathrm{m}$. Dolomites show the lowest values, even along fault routes, since no worthwhile improvement of the hydraulic performance of the indissoluble fissure network has been brought about .In this case values are of few $\mathrm{m}^{3} / \mathrm{h} . \mathrm{m}$ or less (e.g sites 1,2,3,4,15,16, Fig.1) (Kounis et al 1983, Kounis 2008).

The higher values are associated with the dissoluble limestones and calcareous marbles, while hydraulic improvement of their fissure network and an increased karstification along extension preferably faults is the fact (Fig.1, sites 6,7,9,11,13).In this case transmissibility values are mostly in between $10 \mathrm{~m}^{3} / \mathrm{h} . \mathrm{m}$ and $50 \mathrm{~m}^{3} / \mathrm{h} . \mathrm{m}$.

In sites where schist intercalations are frequently present, or some schist boundary is nearby, sufficient reasons for a bad hydraulic performance of the fissure network and even for a hydraulic blockade, the transmissibility is very low to practically extremely low (e.g sites $12,17,18$, Fig.1) .Where carbonates show a densely present fissuring and we attribute the case mostly in a brecciated mass the performance is highly improved, the rest of the favourable factors being present. In this case transmissibility is even greater of $100 \mathrm{~m}^{3} / \mathrm{h} . \mathrm{m}$.

\subsection{Critical yield}

In the hydrogeological decision making the critical yield ( or critical discharge, Qc) of an abstraction well is a useful quantity. Under steady state conditions of flow, it refers to the discharge of the well that divides the set of the pairs of values of the discharge $(\mathrm{Q})$ and the respective drawdown (s) into two domains; the one below the critical yield where drawdown is practically small and increases quite proportionally ( linearly) with the increase of discharge, the other, greater of the critical value, where drawdown is large and goes disproportionally (non - linearly) with the increase of discharge. On an arithmetic graph of Q vs.s the Qc value corresponds to the point of maximum curvature of the curve, and is approximately determined. To precisely find that point, we introduced the transformation $\log Q$ vs. $\log s$, i.e a plot on $\log -\log$ paper .The above defined domains are shown in this transformation by straight lines of which the intersection point corresponds to the critical yield. (Kruseman et al. 1976).

The transformation comes out from the Dupuit formulae, for a steady state radial flow in a full penetrating well,

$$
\begin{gathered}
Q=2 \pi k b(H-h) / \ln (R / r) \quad(\text { confined aquifers) and } \\
Q=\pi k(H-h)(H+h) / \ln (R / r) \quad \text { (unconfined aquifers), }
\end{gathered}
$$




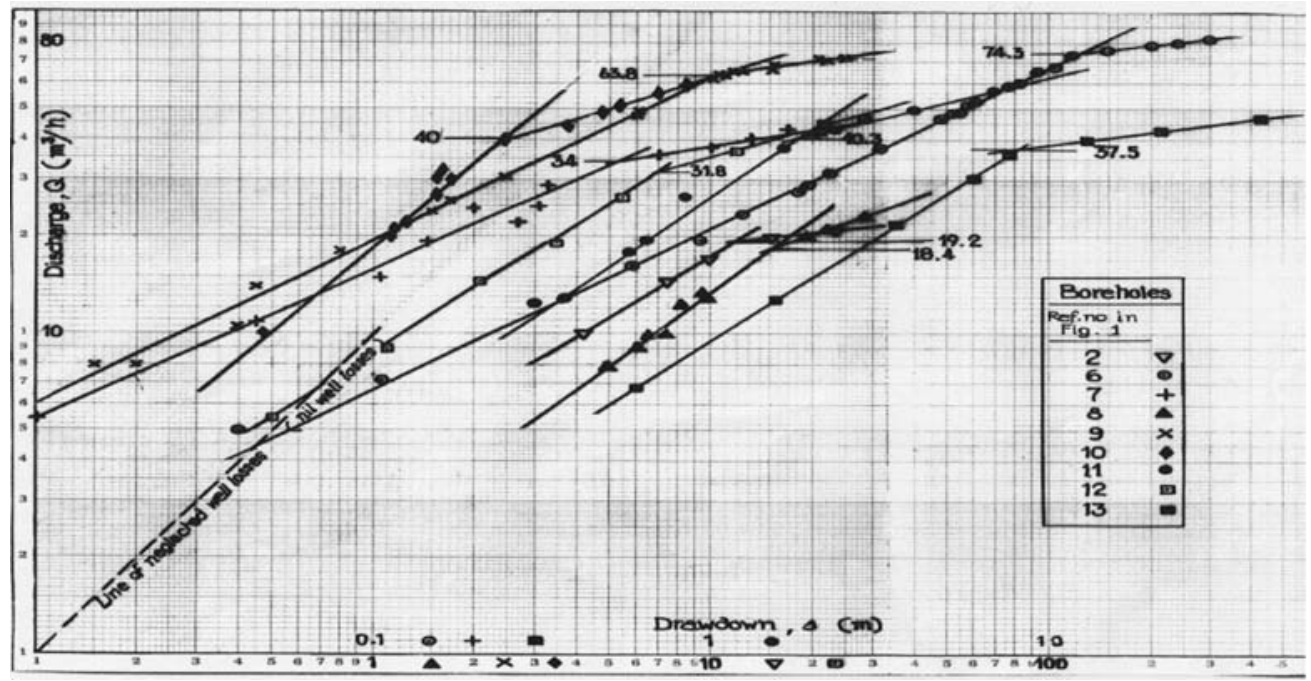

Fig. 2: Indicative curves Q vs. s in $\log -\log$ transformation to precisely appear the critical yield, as the intersection of the straight segments.

where Q, k, b, H, h, R, r stand for well discharge, permeability of the aquifer, thickness of confined aquifer, GW height at distance R from pumped well, GW height in the well, radius of influence of pumped well, well radius respectively, and $\pi=3.14, \mathrm{H}-\mathrm{h}=\mathrm{s}$ the drawdown of the piezometric surface or of the GW level (Bogomolov 1965, Denisov 1957).

The $\log Q$ vs. $\operatorname{logs}$ transformation to exploit a graphical description and solution is apparent. In Fig. 2 are indicatively given some "characteristic curves" of boreholes to show the precise critical yield .Shown also is the line of practically nil well losses, and only of aquifers losses, totally expressed by $\mathrm{s}$, that is the line for

$$
Q=c s
$$

with $\mathrm{c}$ a constant, incorporating all constant quantities of the previous formulae. Yields with no well losses and hence with no energy consumption for them, are very low, as the log-curves of Fig.2 suggest. However, in groundwater exploitation and management the critical yield, as previously defined, is with no doubt preferred, if economic, quality and other constraints allow it. The higher values are offered by carbonate aquifers free of dolomite component, schists intercalations and alike boundaries. If brecciated the aquifer, critical yield is improved.

\section{Conclusions}

- For the natural water balance assessment and studies of fissure/karstic flow carbonate aquifers of the "Eastern Greece geotectonic zone " and of alike formations, an infiltration of approximately 0.4 of the respective precipitation is likely to be the proper figure.

- In same hydrolithology the pertinent specific yield (effective porosity ) is in between 0.015 and 0.043 .

- The transmissibility values that are mostly expected are in between $10 \mathrm{~m}^{3} / \mathrm{h} . \mathrm{m}$ and $75 \mathrm{~m}^{3} / \mathrm{h} . \mathrm{m}$.

- While critical yield of boreholes is most likely to exist in the range of values from $15 \mathrm{~m}^{3} / \mathrm{h}$ to $75 \mathrm{~m}^{3} / \mathrm{h}$ 
- Whatever the aquifer is the $\log \mathrm{Q}$ vs. $\log \mathrm{s}$ transformation offers the precise critical yield of an abstraction well and should be preferred in decisions, while also the annual recession loss from a well hydrograph has to be added in the annual GW level fluctuation to precisely determine specific yield in water balance studies.

- Consequently the hydrogeologist who will be on duty to preliminarly decide on the capabilities of specified hydrogeological sections, abstraction sites or catchments will be safely supported by the above quantities. These will also constructively serve comparative and detailed hydrogeological studies.

\section{References}

Bogomolov, G. 1965. Hydrogeolologie et notions de geologie d' ingenieur .Editions de la Paix, Moscou.

Denisov, N.Ya. 1957.Engineering geology and hydrogeology. State Publishing House for Architecture and Building Literature, Moscow.

Dounas, A., Kallergis, G., Morphis, A., Pagounis, M. 1980. 1976. Hydrogeological investigation of karstic brackish springs of Ag. Apostoli area (Kalamos -Attica). Hydrological and Hydrogeological Investigations. 31. IGME, Athens. (In greek) .

Kounis, G.D.,Vitoriou, A.C., Gioni, G.C., Dimitropoulos, D.C, 1983. Evaluation of groundwater resources in Greece. Institute of Geology and Mineral Exploration, Athens.

Kounis, G.D. 1986. Evaluation of vulnerability and quality of groundwater resourses in Greece. Institute of Geology and Mineral Exploration, Athens.

Kounis, G.D., Siemos, N. 1991. A site hydrogeological investigation of the aquifers of the Thriassion Pedhion for the water supply of the Hellenic Refineries. Institute of Geology and Mineral Exploration, Athens. (In greek).

Kounis, G.D. 1998. A study for the hydrogeology of Attica. Institute of Geology and Mineral Exploration, Athens. (In greek) .

Kounis, G.D., Vitoriou, A. 2005.On the special groundwater quality alluvium aquifer of Loutraki ,in Korinth .Hydrogeological conditions, inflows, outflows and storage. $7^{\text {th }}$ International Hydrogeological Conference. Proceedings V.1, Athens .

Kounis, G. D. 2008. Hydrogeological quantities and findings of particular importance from the hydrogeological structure and performance of Attica, $8^{\text {th }}$ International Hydrogeological Congress of Greece, Proceedings V.2, Athens .

Kruseman, G.P. and De Ridder , N.A. 1976. Analysis and evaluation of pumping test data. International Institute for land Reclamation and Improvement Wageningen, The Netherlands.

Mariolopoulos, I.G., Karapiperis, L.N. 1955. The rainfalls in Greece. National Printing Office - Athens.

Shaw, E.M. 1994. Hydrology in practice. Chapman and Hall,London.

Soulios, G. A contribution to the hydrogeological study of the karstic systems of the greek territory. Scientific Annals of the Faculty of Sciences, Aristotle University ,Vol 3, No27. Thessaloniki. (in greek).

Todd, D.K. 1959. Groundwater hydrology. John Wiley and Sons, NewYork.

Wilson, E.W. 1993. Engineering Hydrology. McMillan, London. 